Louisiana State University

LSU Digital Commons

Faculty Publications

Department of Oceanography \& Coastal

Sciences

1994

\title{
Backfilling Canals to Restore Wetlands: Empirical Results in Coastal Louisiana
}

R. Eugene Turner

euturne@lsu.edu

James M. Lee

Christopher Neill

Follow this and additional works at: https://digitalcommons.Isu.edu/oceanography_coastal_pubs

Part of the Oceanography Commons

\section{Recommended Citation}

Turner, R., Lee, J. M., \& Neill, C. (1994). Backfilling Canals to Restore Wetlands: Empirical Results in Coastal Louisiana. Wetlands Ecology and Management, 3 (1), 63-78. Retrieved from

https://digitalcommons.Isu.edu/oceanography_coastal_pubs/149

This Article is brought to you for free and open access by the Department of Oceanography \& Coastal Sciences at LSU Digital Commons. It has been accepted for inclusion in Faculty Publications by an authorized administrator of LSU Digital Commons. For more information, please contact ir@lsu.edu. 


\title{
Backfilling canals to restore wetlands: empirical results in coastal Louisiana
}

\author{
R. Eugene Turner ${ }^{1}$, James M. Lee ${ }^{1}$ and Christopher Neill ${ }^{2}$ \\ ${ }^{I}$ Coastal Ecology Institute, Louisiana State University, Baton Rouge, LA 70803, USA; ${ }^{2}$ The Ecosystem \\ Center, Marine Biological Laboratory, Woods Hole, MA 02543, USA
}

Keywords: Saltmarsh, Spartina alterniflora, restoration, Louisiana, mitigation

\begin{abstract}
Wetland restoration is largely a developing science and engineering enterprise. Analyses of results are too few and constrained to observations over a few years. We report here on the effectiveness of one restoration technique used sparsely in coastal Louisiana for several decades. Canals have been dredged in coastal Louisiana wetlands since 1938 for oil and gas exploration and extraction. These canals are typically dredged to $2.5 \mathrm{~m}$ depth and are 20 to $40 \mathrm{~m}$ wide. Canal lengths vary from $100 \mathrm{~m}$ to several $1000 \mathrm{~s} \mathrm{~m}$ in the case of outer continental shelf pipeline canals that cross the wetlands.

Today, thousands of miles of canals crisscross these wetlands. Studies have linked dredged canals to a number of undesirable effects on the wetland environment including alterations in salinity, flooding and drainage patterns, direct loss of marsh by convention to open water, and increases in marsh erosion rates. These effects have led state and federal agencies charged with managing the wetland resource to look for methods of mitigating canal impacts. One possible method of managing spoil banks after the abandonment of a drilling site is to return spoil material from the spoil banks to the canal with the hope that marsh vegetation will be reestablished on the old spoil banks and in the canal. The movement of former spoil bank material back into the canal is referred to as 'backfilling'.

The purpose of this study was to (1) examine how backfilled canals changed over 10 years, (2) examine factors influencing success with multiple regression statistical models, and, (3) compare costs of backfilling with other Louisiana marsh restoartion projects. We examined the sites to document and interpret changes occurring since 1983/4 and to statistically model the combined data derived from these new and previous analyses. Specifically, we wanted to determine the recovery rates of vegetation, water depth, and soils in backfilled canals, 'restored' spoil banks, and in nearby marshes, and to quantify the influence of plugging canals on these rates.

The major factors determining backfilling restoration success are the depth of the canal, soil type, canal dimensions, locale, dredge operator skill, and permitting conditions. Plugging the canal has no apparent effect on water depth or vegetation cover, with the exception that submerged aquatic vegetation may be more frequently observed behind backfilled canals with plugs than in backfilled canals without plugs. Canal age, soil organic matter content, and whether restoration was done as mitigation on-site or off-site were the most important predictors of final canal depth. Canal length and percentage of spoil returned $(+)$ had the greatest effect on the restoration of vegetation cover. Backfilled canals were shallower if they were older, in soils lower in organic matter, and backfilled off-site. Backfilling the canal restores wetlands at a cost of $\$ 1,200$ to $\$ 3,400 /$ ha, which compares very favorably with planned restoration projects in south Louisiana.
\end{abstract}




\section{Introduction}

Wetland restoration and mitigation is a relatively new management issue that has too few examples of quantified success for projects lasting decades. However, in Louisiana the restoration of wetlands by filling in dredged canals has been accomplished at a few sites for up to 30 years. Most canals have been dredged in coastal Louisiana wetlands for oil and gas exploration and extraction since 1938 . These waterways are usually abandoned after mineral extraction and thousands of miles of canals now crisscross these wetlands. These canals are typically dredged to $2.5 \mathrm{~m}$ depth and are 20 to $40 \mathrm{~m}$ wide and canal lengths vary from $100 \mathrm{~m}$ to several $\mathrm{km}$ in the case of pipeline canals from offshore oil and gas reserves.

Studies have linked dredged canals to a number of undesirable effects on the wetland environment. These effects include alterations in salinity, flooding and draining patterns, direct loss of marsh by conversion to open water, and indirectly caused marsh losses (Craig et al. 1979, Gagliano et al. 1981, Swenson and Turner 1987, Cahoon and Turner 1989). Direct and indirect impacts of canals and spoil banks are the likely cause for 30 to 59 percent of the coastal wetland losses from 1955 to 1978 (Turner and Cahoon 1987).

These impacts have led state and federal agencies charged with managing wetland resources to look for methods of mitigating canal impacts. One possible method of dealing with spoil banks after the abandonment of a drilling site is to return material from the spoil banks back to the canal. The intention of this method is to reestablish marsh on the old spoil banks and in the canal and to return to a more natural hydrological regime. The re-dredging of former spoil bank material back into the canal is referred to as 'backfilling'.

Backfilling began to be required in some instances, starting in 1979 (Neill and Turner 1985, 1987a) as a condition for the issuance of permits to dredge a canal (after the drilling site is abandoned the canal must be backfilled) or as off-site mitigation for the issuance of a permit for a new canal.
Evaluations of backfilling as mitigation

Thirty-three backfilled canals, representing almost all permitted backfilling of oil and gas canals, were assessed by Neill and Turner $(1985,1987 a)$ to document the initial success of habitat restoration. Restoration success appeared to depend on marsh type, canal location and age, marsh soil characteristics, the presence or absence of a plug at the canal mouth, whether mitigation was conducted at the dredging site upon canal abandonment (on-site mitigation) or away from the permit location (offsite mitigation), and dredge operator performance. Backfilling initially reduced the median canal depth from 2.4 to $1.1 \mathrm{~m}$ and restored marsh vegetatio on the backfilled spoil bank, but did not then result in restoration of the emergent marsh vegetation in the canal because of the lack of sufficient spoil material to fill the canal and/or time. The organic matter and water content of spoil bank soil were intermediate between spoil bank levels and pre-dredging marsh conditions.

Backfilling has great potential for improving unfilled canals as aquatic hatitat for fish and wildlife (Turner et al. 1988). Backfilling initially creates shallow open water areas in the former canal that support large numbers of small fishes, including juveniles of species that use shallow marsh water bodies as nurseries (Neill and Turner 1987b). Backfilled canals often bear a visual resemblance to natural marsh ponds, have similar dimensions, support aquatic vegetation, and have a high amount of marsh-water edge. Such shallow marsh ponds have been widely shown to be excellent habitat for estuarine fishes and macroinvertebrates (Perry 1976, Weinstein 1979, Bozeman and Dean 1980). One study found that the mean annual abundance of macrofauna in a backfilled canal was similar to a natural creeke and double the abundance in an unfilled canal (Sikora and Sikora 1984). Mean annual abundance of meiofauna was six times greater in the backfilled canal than in the unfilled canal. The unfilled canal was classified as a highly disturbed benthic habitat, where the abundance of macro- and meiofauna appeared to be controlled by low levels of dissolved oxygen and high sulfide levels (Sikora and Sikora 1984). Benthic popula- 
tions in the backfilled canal appeared to be controlled by biotic factors such as predation, rather than physical factors.

Backfilled canals also have the potential to be high quality habitat for waterflow because they often contain at least some species of aquatic vegetation important to waterflow including: widgeongrass (Ruppia maritma), dwarf spikerush (Eleocharis parvula), floating waterprimrose (Ludwigia peploides), coontail Ceratophyllum demersum), southern naiad (Najas quadalupensis), fanwort (Cabomba caroliniana), and duckweed (Lemna minor). Shallow open water areas in backfilled canals or on backfilled spoil banks are often less than $50 \mathrm{~cm}$ deep, a depth that can potentially be used by dabbling ducks for feeding (Chabreck 1979, Fredrickson and Drobney 1979).

In Louisiana, oil and gas canals are often plugged upon abandonment with earthen or shell dams (also known as plugs) approximately 30 $60 \mathrm{~cm}$ above the elevation of surrounding marshes. Plugs are designed to maintain elevated marsh water levels, prevent salt water intrusion into low-salinity marshes, and reduce tidal exchange thereby reducing bank erosion. However, by limiting the tidal exchange between canal and adjacent waterbody, plugs also interfere with the movement of aquatic organisms and may significantly reduce the area of potentially suitable habitat. Plugs may induce erosion by forcing water to drain elsewhere, particularly around the plug. Plugging canals encourages the growth of submerged aquatic vegetation, but also restricts the access of migratory estuarine fishes (Neill and Turner 1987a, b).

\section{Purpose of current study}

We examined the sites of Neill and Turner (1987a) to document and interpret changes occurring since 1983/4 (the data of their field surveys) and to statistically model the combined data derived from these new and previous analyses. Specifically, we wanted to determine the recovery rates of vegetation, water depth, and soils in backfilled canals, 'restored' spoil banks, and in nearby marshes, and quantify the influence of plugging canals on these rates. We wanted to know if the initial growth of submerged aquatic vegetation was maintained, if additional growth appeared, and if the growth of submerged aquatics was sustained only until the plug washed out. We also estimated the costs of backfilling to compare with other restoration techniques.

\section{Materials and methods}

The backfilled canals examined by Neill and Turner (1987a, their Fig. 1) in 1983/4 were re-examined by aerial imagery and field visits to determine recent changes in soils and vegetative cover. A statistical model of the data was constructed using the resulting data. Hypotheses tested about restoration through backfilling were that success is a function of: (1) canal length, (2) canal age, (3) marsh soil organic matter content, (4) presence of a plug at the mouth of the canal, and (5) the percentage of the available spoil material returned to the canal.

\section{Aerial imagery}

All canals were photographed in color infra-red imagery in November 1990 using an aircraftmounted large-format (5 inch $\times 5$ inch) camera from an altitude of approximately $916 \mathrm{~m}$. An 8 inch $\times 8$ inch photograph was developed from the resulting transparency to determine the percentage of the old spoil bank area that is now marsh vegetation, upland vegetation, and open water (by planimeter). The 1990 photography was also visually compared to black and white oblique photographs taken during the earlier study.

\section{Canal depth and vegetation}

Canal depths were determined on the site visits conducted in June 1991 and July 1992. Point measurements were made at $10 \mathrm{~m}$ intervals up the canal axis. Because water level records are not available for widely scattered locations, we measured elevation relative to mean elevation of adjacent marsh 
rather than to mean water level (as previously). Sasser (1977) found that mean marsh elevation was not distinguishable statistically from mean water level for marshes composed of most important Louisiana marsh plant species.

We determined the presence/absence and species of submerged aquatic vegetation from ground observations. Changes in vegetation and water surface area were made by comparing measurements made in 1983/4 and 1992.

\section{Plug condition}

Both aerial photographs and ground observations were used to determine the status of the plug at the mouth of the canal (plugged, unplugged, partially plugged), and, the percentage of the spoil bank returned to the canal during backfilling from aerial photographs and ground observations.

\section{Descriptive statistics}

The effects of restoration of marsh type, hydrologic unit, presence of a plug, and whether mitigation was for the dredged location (on-site mitigation) or for one at another location (off-site mitigation) were examined by calculating mean values for depth, plant cover, and spoil returned for each marsh type, hydrologic unit, plug and mitigation circumstances. The canals examined represented a high proportion of all existing backfilled canals and therefore represented a finite population. The standard error of the mean (S.E.) for each category was calculated as:

$$
\text { S.E. }=\sqrt{\frac{s^{2}}{n} \frac{(N-n)}{N}}
$$

where $\mathrm{N}$ equals the number of all existing backfilled canals, $s$ equals the sample variance and $n$ equals the number of canals sampled (Snedecor and Cochran 1967). A standard error of zero indicates that all existing canals in that category were sampled and the mean was determined exactly. These data were used in the statistical analysis (below).

\section{Statistical models}

Simple linear and quadratic regression models were developed relating canal water depth to canal age. We developed multiple regression models to investigate the factors affecting the success of marsh restoration by canal backfilling. Success was measured by canal depth and by cover of marsh vegetation on the restored canal and spoil bank. We hypothesized success to be a function of: (1) canal length, (2) canal age at backfilling, (3) marsh soil organic matter content, (4) presence of a canal plug, (5) whether backfilling was performed for mitigation upon abandonment (on-site mitigation) or away from the permitted location (or offsite mitigation), and (6) the percentage of the available spoil material that was returned to the canal. All hypothesis tests were performed at the 95 percent significance level.

Two separate models were developed using the same independent variables (1-6 above). The dependent variable in one case was canal depth, and in the other case, vegatation cover. The relation is given by:

$$
\underset{B_{7} X_{7}}{Y_{i}}=B_{1}+B_{2} X_{2}+B_{3} X_{3}+B_{4} X_{4}+B_{5} X_{5}+B_{6} X_{6}+
$$

where:

$\mathrm{Y}=$ canal depth in meters, or percent cover of marsh vegetation on the backfilled spoil bank,

and,

$\mathrm{X}_{2}=$ canal length in $\mathrm{m}$,

$\mathrm{X}_{3}=$ age of canal at time of backfilling (in months),

$\mathrm{X}_{4}=$ percent soil organic matter,

$\mathrm{X}_{5}=$ presence of a canal plug $\mathrm{l}$, if plug present; 0 , if plug absent

$\mathrm{X}_{6}=$ permit conditions 1 , if backfilled off-site; 0 , if backfilled as on-site mitigation

$\mathrm{X}_{7}=$ percent of spoil material returned to the canal

and,

$B_{i}=$ the non-dimensional coefficient for each variable ' $i$ ', 1 to 7

Data for the model consisted of information on the 
23 canals for which all $\mathrm{X}$ - and Y-data were available.

The vegetation cover on the backfilled spoil banks was used as a measure of restoration success instead of vegetation cover in the canal because there was not a wide range of vegetation re-establishment in the canal. In most cases less than 10 percent of the canal was converted to marsh (Neill and Turner 1987a). In only one case was more than 50 percent of the canal area re-vegetated to marsh.

Six hypotheses (HO) were tested about the effect of backfilling.

HO canal length: Canal length was hypothesized to positively affect restoration success because more spoil material should allow greater filling. Longer canals also were thought to allow for better vegetation re-establishment. Because backfilling is rarely used, it was thought that dredge operators did not possess the skills to expertly level spoil banks. This skill is important because if too much spoil is left unfilled, the elevation is too great for marsh plant re-colonization. Conversely, if too much spoil is backfilled, the elevation is too low for plant re-colonization. It was thought that longer canals would allow more area for operator 'practice'. Over the course of filling a long canal, an operator could refine his technique, allowing more precise spoil leveling and greater marsh re-establishment.

HO canal age: Canal age was hypothesized to be inversely related to filling and restoration success. In general, the older a spoil bank is, the less its volume. This results from the oxidation of highly organic marsh soils as they dry when exposed as a spoil bank. Greater age and lower spoil bank volume was anticipated to decrease the level of vegetation colonization, because marsh plants are less likely to re-colonize the older, more compacted soils of old spoil banks.

HO soil organics: Soil organic matter content was thought to inversely affect canal depth and vegetation re-colonization. Most organic soils lose more volume more rapidly and lose greater total volume compared with less organic soils in spoil banks of similar age. This leaves less material as fill, and decreases the amount of vegetation re-establishment.
$H O$ canal plug: Plugs were thought to decrease depth and increase the amount of vegetation restored by preventing fill from washing out of the canal and by preventing erosion of the vegetated banks of the canal.

$H O$ permit condition: Backfilling was hypothesized to be more successful if the permit was issued to backfill canals off-site rather than after dry well abandonment. This was anticipated because drillers, when doing mitigation, have a choice of which canal to fill. Thus, they might choose canals that they presume (for whatever reasons) to have a high potential for restoration success, both for filling and for vegetation re-establishment. A driller's choice of canals for restoration may, however, be motivated by economic considerations (property access, property ownership, etc.) in which case permit condition may have little influence on restoration.

HO spoil returned: The amount of spoil returned to the canal was anticipated to have a direct relationship to restoration success. The greater the percentage of spoil returned, the shallower the depth. Similarly, the more spoil returned, the lower the elevation of the spoil bank after backfilling, and the more vegetation re-establishment. This would be true to the point when spoil was dug deeper than marsh elevation, creating more open water. Although this was a problem in some localized spots on some spoil banks, rarely was 100 percent of the spoil returned. Therefore, vegetation restoration was thought to increase with increasing spoil returned.

\section{Subjective measures of success}

The final approach was a subjective evaluation of success based on the following criteria:

1. In-filling of former canal area; establishment of some emergent marsh vegetation;

2. Blending of former spoil bank with surrounding marsh (similar vegetation);

3. Establishment of hydrologic connection and natural drainage among canal, former spoil 


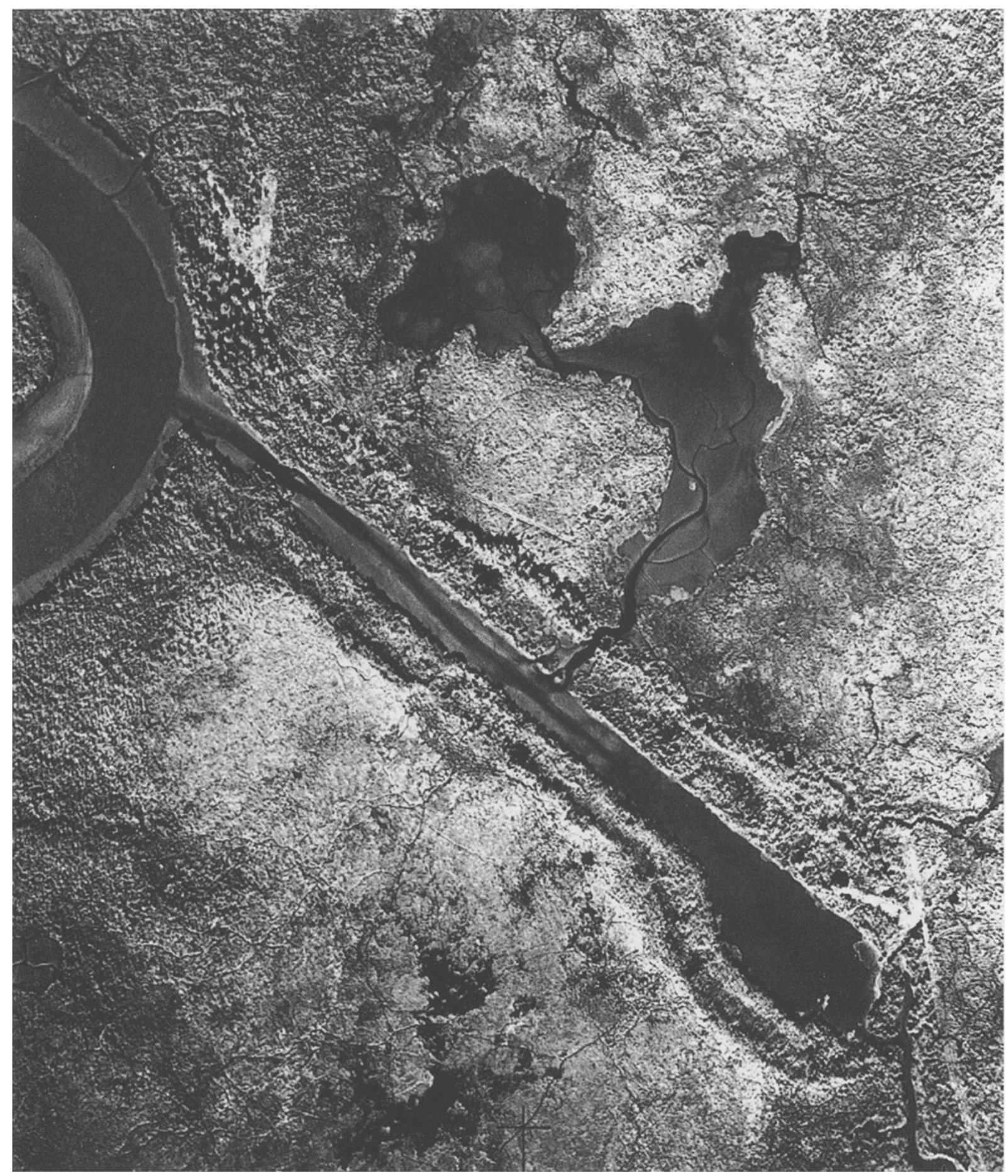

Fig. 1. An aerial infrared image of the backfilled canal at Vermillion River (site \# 13). 


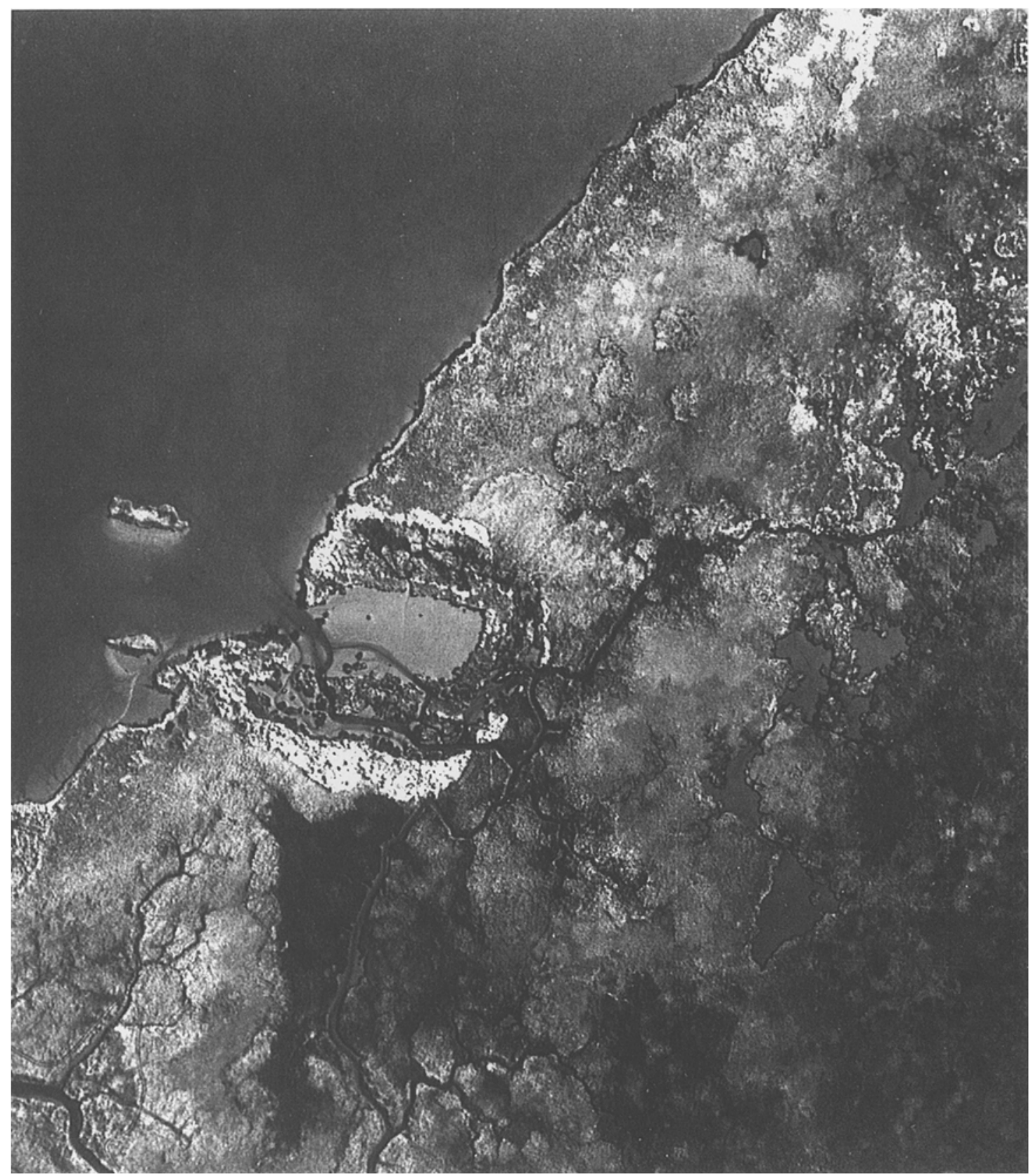

Fig. 2. An aerial infrared image of the backfilled canal at Lower Mud Lake (site \# 25).

bank, surrounding marsh and nearby bodies of water;

4. No major conversion of former spoil bank to open water.
Each of the four categories were examined and a rank of 0 to 3 applied to each of them. The individual 4 scores were summed to obtain an overall ranking of restoration success. 


\section{Results}

\section{Water depth}

There was no measurable increase or decrease in water depth from the $1983 / 4$ period to the $1991 / 2$ sampling period (Table 1). However, the data set was limited to 7 sites with measurements in both periods. Several canals were too shallow to penetrate because of low water or floating aquatics (principally hyacinth). An additional methodological issue was that the measurements were made down the throat of the canal. Several sites had obviously filled in along the edges of the canal or had streams cutting into or across the former canal spoil bank (Figs 1 and 2) and the average depth was impossible to determine using the techniques of Neill and Turner (1987a). Therefore the data set has a rather limited usefulness for comparative purposes.

The average water depth at each site was empirically related to the time between dredging and backfilling (Fig. 3). The depth initially rose with increasing time, but then declined after about 5 years. This result is consistent with the hypothesis that the dredged spoil material is washing away or

Table 1 . The mean and \pm 1 Standard Deviation for paired sites (number $=\mathrm{n}$ ) in the two study periods

\begin{tabular}{|c|c|c|}
\hline & Mean (n) & Std. Dev. \\
\hline \multicolumn{3}{|c|}{ Percent Marsh in Canal $(n=30)$} \\
\hline $1983 / 4$ & 5.3 & 9.8 \\
\hline $1992 / 3$ & 5.1 & 14.4 \\
\hline \multicolumn{3}{|c|}{ Percent Marsh on Spoil $(n=30)$} \\
\hline $1983 / 4$ & 47.2 & 27.1 \\
\hline $1992 / 3$ & 50.7 & 23.6 \\
\hline \multicolumn{3}{|c|}{ Percent Open Water on Spoil $(n=30)$} \\
\hline $1983 / 4$ & 24.4 & 23.0 \\
\hline $1992 / 3$ & 23.3 & 20.5 \\
\hline \multicolumn{3}{|c|}{ Percent Upland Vegetation on Spoil $(n=30)$} \\
\hline $1983 / 4$ & 28.4 & 26.5 \\
\hline $1992 / 3$ & 25.5 & 23.3 \\
\hline \multicolumn{3}{|c|}{ Depth of Canal $(n=8)$} \\
\hline $1983 / 4$ & 111.3 & 16.3 \\
\hline $1992 / 3$ & 121.1 & 20.2 \\
\hline \multicolumn{3}{|c|}{ Percent Organic $(n=16)$} \\
\hline $1983 / 4$ & 48.1 & 18.1 \\
\hline $1992 / 3$ & 40.9 & 22.6 \\
\hline
\end{tabular}

oxidizing as it is exposed to air after placement on the wetland, and that there is subsequently less to return to the canal with time. The declining depth after 5 years is probably related to the filling in of the canal before backfilling. This long-term annual fill rate was about $5.8 \mathrm{cmyr}^{-1}$ (Fig. 4). Later, in the statistical modeling section, we estimate the fill rate to be about $4.2 \mathrm{cmyr}^{-1}$, when the influence of all other factors is normalized through statistical analyses. We subtracted this long-term rate (4.2 $\mathrm{cmyr}^{-1}$ ) from the total depth, to derive the fillrate from backfilling alone, over time (Fig. 5). These results indicate that the effectiveness of backfilling continues for about 2 decades after dredging. Beyond that point backfilling probably will not have much influence on canal depth.

\section{Canal and spoil bank restoration}

The measured sizes of each site were nearly identical for the 1983/4 and 1992/3 samplings (Fig. 6).

The overall average percent vegetation in the canals and in the spoil banks remained unchanged during 1983/4 to 1990 (Table 1). This result is consistent with the slow or stable canal infilling during the interval. Vegetation does not re-colonize until water depths are less than $0.6 \mathrm{~m}$ (Fig. 7). The spoil

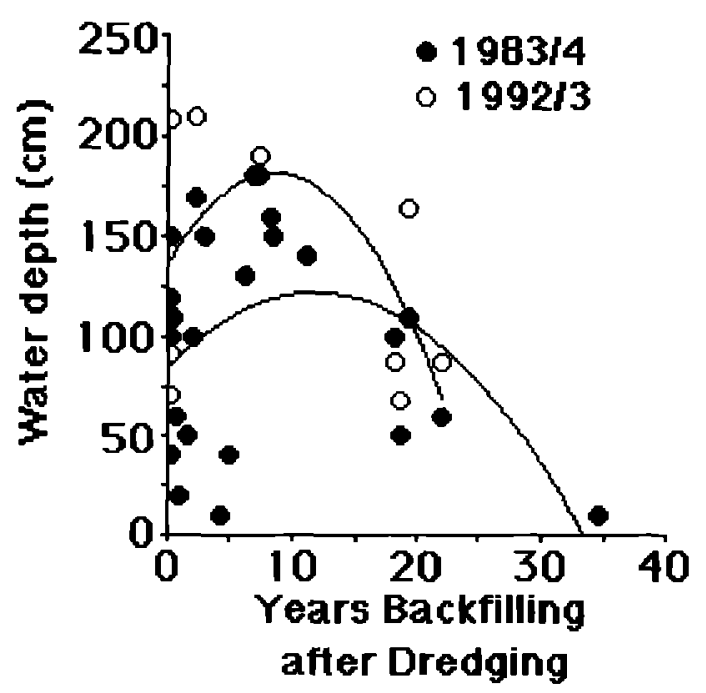

Fig. 3. Water depth in 1983/4 and in 1992/3 versus the years between the original dredging and backfilling. 


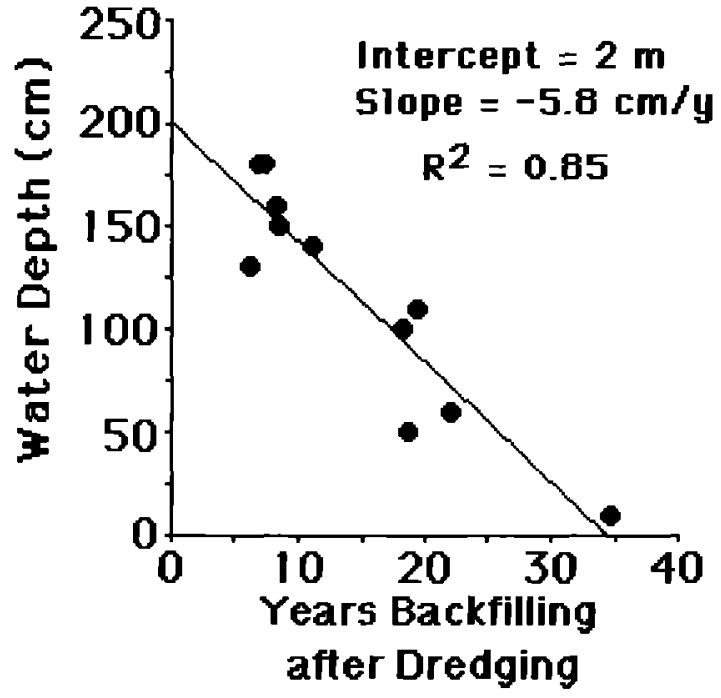

Fig. 4. Water depth in 1992/3 versus the years between the original dredging and backfilling. Only sites that were dredged $>5$ years before backfilling are shown. The straight line is a linear regression of the two variables.

bank is the dominant location of restored wetland area at all sites.

\section{Measures of success}

The subjective ranking of restoration success at all sites varied greatly, and no site showed 100 percent restoration success (Fig. 8). Some remained virtually unchanged since the survey of Neill and Turner (1987a). Others had enough sedimentation to prohibit boat traffic. Site rank and water depth were inversely related.

\section{Statistical models of change}

\section{Canal depth model}

The results obtained from the statistical model of canal depth are presented in Table 2. The coefficient for canal length indicated that length had little effect on depth and we failed to reject the null hypothesis that $B_{2}=0$. We therefore conclude that canal length had no influence on restoration success in terms of canal depth.

The coefficient for age $\left(\mathrm{X}_{3}\right)$ indicated that age is inversely related to depth. A one month increase in

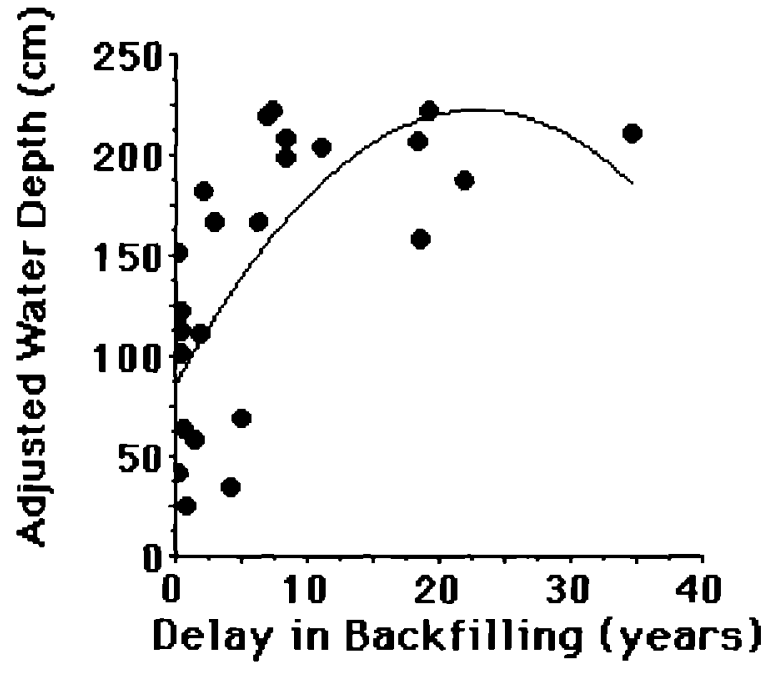

Fig. 5. The estimated water depth versus the years between the original dredging and backfilling, corected for the long-term fill rate. Only sites that were dredged less than 10 years before backfilling are shown. The actual water depth was adjusted for filling in of canal without dredging time between by subtracting the fill rate of the previous figure. The curved line is a polynomial regression of the two variables.

the canal age at backfilling results in a $0.35 \mathrm{~cm}$ decrease in canal depth, or $4.2 \mathrm{cmyr}^{-1}$. This rate is slightly lower than the rate of $5.8 \mathrm{cmyr}^{-1}$ estimated from the linear regression (Fig. 4). We rejected the null hypothesis that $\mathrm{B}_{3}=0$ and conclude that restoration success increases with time.

Each percent increase in soil organic matter $\left(\mathrm{X}_{4}\right)$ content results in an increase in canal depth of

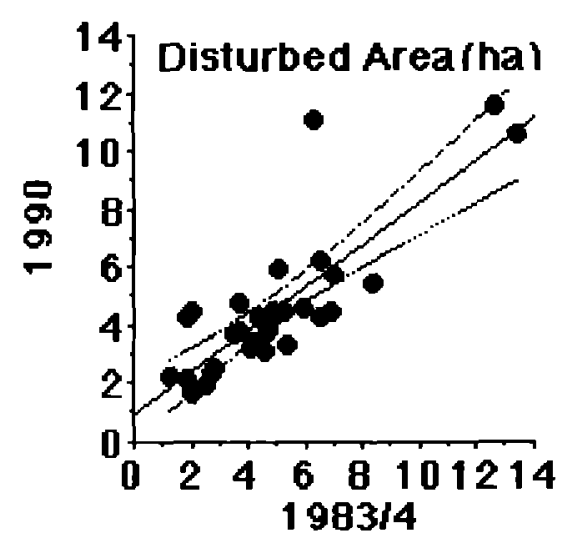

Fig. 6. A comparison of the estimate of the disturbed area from the 2 studies (1983/4 and 1990/2). A linear regression of the two variables is the solid line. The 95 percent Confidence Interval for the true value of the $y$ intercept is shown with the dotted line. There is no difference in the size of the areas from one study period to the next. 


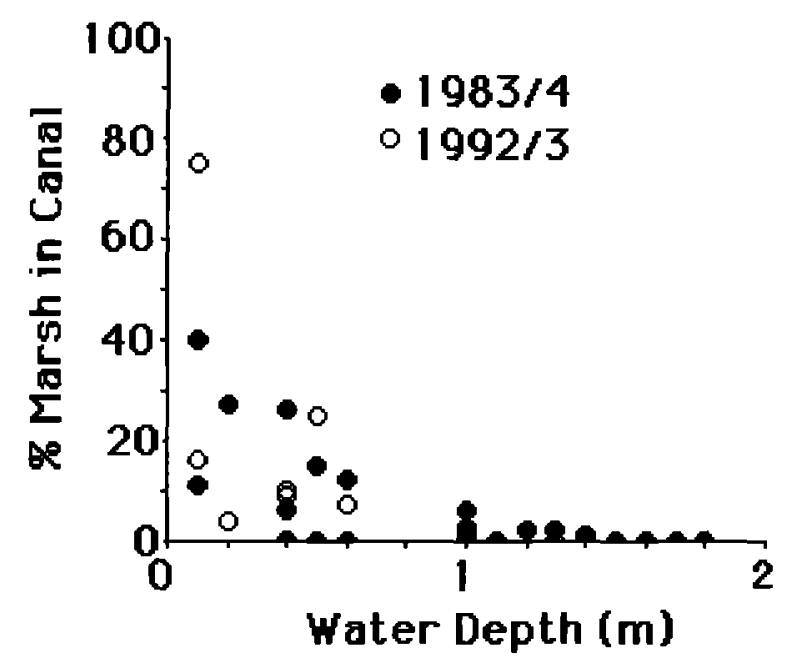

Fig. 7. The relationship between the percent vegetation in the canal and water depth for the two studies.

$1.5 \mathrm{~cm}$. We rejected the null hypothesis that $B_{4}=0$ and conclude that soil organic matter concentration influences restoration success.

Plugged canals $\left(\mathrm{X}_{5}\right)$ are $4 \mathrm{~cm}$ shallower than unplugged canals, but we fail to reject the null hypothesis that $\mathrm{B}_{5}=0$, and conclude that plugs have no effect on canal depth.

The coefficient for Permit Condition $\left(\mathrm{X}_{6}\right)$ indicates that canals backfilled as mitigation away from the permitted site (off-site mitigation) are $0.6 \mathrm{~m}$ shallower than canals backfilled after dry hole abandonment (on-site mitigation). We rejected the null hypothesis that $B_{6}=0$.

The amount of spoil returned $\left(X_{7}\right)$ had little effect on the depth of the canal. We fail to reject the null hypothesis that $\mathrm{B}_{7}=0$ and conclude that the

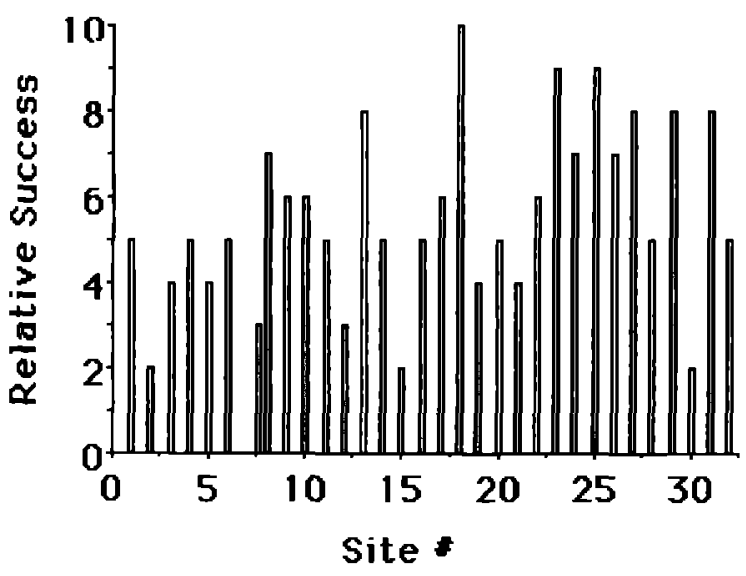

Fig. 8. The ranking of backfilling success using an arbitrary scale for hydrologica connection, re-vegetation, and vegetation cover. A ' 12 ' is $100 \%$ restoration success.

variability in spoil return was not a significant influence on the variability in canal depth. This result should not be interpreted to mean that backfilling any amount of spoil bank material has no influence on canal depth - something that is counter-intuitive. The model results probably mean that variability in the amount returned at the time of backfilling is not as important as the variability in the other factors, e.g., the variability in site characteristics.

The sign of the coefficient for age $\left(\mathrm{B}_{3}\right)$ differs from the hypothesized relationship. Older canals appear, on average, to be shallower than younger ones.

Vegetation cover model

The results obtained from the statistical model of

Table 2. Results of the model to predict canal depth.

\begin{tabular}{|c|c|c|c|c|}
\hline \multirow[t]{2}{*}{ Variable } & \multicolumn{4}{|c|}{ d.f. $=17 ; R^{2}=0.55$} \\
\hline & Beta & Std. Error & $\mathrm{T}$ Value & \\
\hline $\mathrm{X}_{\mathrm{I}}$ Intercept & 0.47 & & & \\
\hline$X_{2}$ Length & 0.0001 & 0.001 & 0.96 & NS \\
\hline$X_{1}$ Age & -0.0035 & 0.0013 & 2.8 & $*$ \\
\hline $\mathrm{X}_{4}$ Percentage Organic & 0.015 & 0.0055 & 2.7 & $*$ \\
\hline$X_{5}$ Plug & -0.0085 & 0.27 & 0.31 & NS \\
\hline $\mathrm{X}_{6}$ Permit Condition & 0.58 & 0.28 & 2.1 & $*$ \\
\hline $\mathrm{X}_{7}$ Percent Returned & -0.0029 & 0.0067 & 0.43 & NS \\
\hline
\end{tabular}

* significant at the $95 \%$ level. 
Table 3. Results of the model to predit vegetation restoration.

\begin{tabular}{|c|c|c|c|c|}
\hline \multirow[t]{2}{*}{ Variable } & \multicolumn{4}{|c|}{ d.f. $=19 ; R^{2}=0.55$} \\
\hline & Beta & Std. Error & $\mathrm{T}$ Value & \\
\hline X1 Intercept & -7.8 & & & \\
\hline X2 Lenght & 0.13 & 0.041 & 3.2 & $* *$ \\
\hline X3 Age & -0.13 & 0.045 & 2.8 & $* *$ \\
\hline X4 Percent Organic & -0.21 & 0.22 & 0.97 & NS \\
\hline X5 Plug & -12.9 & 10.8 & 1.2 & NS \\
\hline X6 Permit Condition & 10.9 & 12.2 & 0.89 & NS \\
\hline X7 Percent Returned & 0.64 & 0.28 & 2.3 & $*$ \\
\hline
\end{tabular}

* significant at the $95 \%$ level.

** significant at the $99 \%$ level.

vegetation restoration are in Table 3 . The coefficient for length indicated that each $m$ increase in canal length resulted in an 13 percent increase in cover for each $100 \mathrm{~m}$ increase in length (over the size range of canals sampled). We rejected the hypothesis that $\mathrm{B}_{2}=0$. Therefore, vegetation cover appears to be influenced by canal length.

The coefficient for age indicated that older canals have less vegetation restoration on the former spoil banks than younger canals. We could not reject the null hypothesis that $B_{3}=0$. We cannot explain this result to our satisfaction, especially in view of the stable composition of the vegetation cover between the 2 surveys.

Each percentage increase in soil organic matter resulted in a decrease of 0.21 percent in vegetation cover, but again we fail to reject the null hypothesis that $\mathrm{B}_{4}=0$ and conclude that the differences with age were not statistically significant.

Plugged canals had 13 percent less vegetation cover on the spoil bank, but we failed to reject the null hypothesis that $\mathrm{B}_{5}=0$, and conclude that the differences with and without plugs were not statistically significant.

Canals backfilled as mitigation had 11 percent more vegetation cover than canals backfilled after abandonment, according to the estimate of $B_{6}$. However, we failed to reject the null hypothesis that $\mathrm{B}_{6}=0$.

According to the estimate of $\mathrm{B}_{7}$, each percentage increase in spoil returned to the canal resulted in a 0.64 percent increase in the percentage cover of vegetation. We rejected the null hypothesis that $\mathrm{B}_{7}=0$.

Detection of interdependence of independent variables

For various reasons, we may expect some of the independent variables to be related to each other. For instance, we expect canals backfilled after well abandonment to be younger than canals backfilled as mitigation. The pair-wise correlation between $X_{3}$ and $X_{6}$ (age and permit condition, respectively) is 0.64. Canal age and length had a pair-wise correlation of 0.51 , indicating that older canals tend to be longer. This is probably related to tighter restrictions on new canal construction and/or a reduced path needed to dredge in wetlands with wetlands. There were no pair-wise correlations above 0.8 , the level that indicates serious multi-colinearity.

Regressions of each explanatory variable against all other explanatory variables revealed that 44 percent of the variation in length can be ex-

Table 4. Regressions of each explanatory variable against all others.

\begin{tabular}{lll}
\hline Dependent variable & \multicolumn{2}{l}{ Variables with slopes } \\
\cline { 2 - 3 } & $\mathrm{R}^{2}$ & $\mathrm{~N}$, where $\mathrm{t}=0$ at 95 percent Level \\
\hline $\mathrm{X}_{2}$ lenght & 0.45 & $\mathrm{X}_{3}$, age \\
$\mathrm{X}_{3}$ age & 0.60 & $\mathrm{X}_{2}$, length; $\mathrm{X}_{6}$, permit \\
$\mathrm{X}_{4}$ percent organic & 0.08 & - \\
$\mathrm{X}_{5}$ plug & 0.07 & - \\
$\mathrm{X}_{6}$ permit & 0.55 & $\mathrm{X}_{3}$, age \\
$\mathrm{X}_{7}$ return & 0.36 & - \\
\hline
\end{tabular}


plained by a linear combination of the other variables and that the only variable in this model with a slope that is significantly different from zero at the 95 percent level was canal age (Table 4). Sixty percent of the differences in age could be explained by a linear combination of the other variables. Slopes of length and permit condition were significantly different from zero. Fifty-five percent of the variation in permit condition was explained by a combination of the other variables, and the slope of canal age was positive and significantly different from zero at the 95 percent level. Only 6 percent of the variation in organic matter content, 7 percent of the variation in the presence of a plug, and 36 percent of the variation in spoil returned could be explained by linear combinations of the other X-data. Clearly, the greatest interdependence exists between length, age, and permit condition.

Table 5. Effect of deletion of three observations to the depth and vegetation restoration models.

\begin{tabular}{|c|c|c|c|c|}
\hline \multirow[t]{2}{*}{ Variable } & \multicolumn{4}{|c|}{$\begin{array}{l}\text { Depth Model } \\
\mathrm{R}_{2}=0.63\end{array}$} \\
\hline & Beta & Std. Error & T-Value & \\
\hline $\mathbf{X}_{1}$ & -0.071 & 0.74 & 0.1 & NS \\
\hline$X_{2}$ & $0.000 \mathrm{I}$ & 0.0001 & 1.3 & NS \\
\hline$X_{3}$ & 0.0045 & 0.0014 & -3.1 & $* *$ \\
\hline$X_{4}$ & 0.015 & 0.0051 & 2.9 & $* *$ \\
\hline $\mathrm{X}_{5}$ & -0.070 & 0.22 & -0.31 & NS \\
\hline$X_{6}$ & 0.82 & 0.30 & 2.8 & * \\
\hline $\mathrm{X}_{7}$ & 0.0014 & 0.0076 & 0.18 & NS \\
\hline \multirow[t]{2}{*}{ Variable } & \multicolumn{4}{|c|}{$\begin{array}{l}\text { Vegetation Restoration Model } \\
\mathrm{R}^{2}=0.75\end{array}$} \\
\hline & Beta & Std. Error & T-Value & \\
\hline $\mathrm{X}_{1}$ & -16.8 & 29 & -0.58 & NS \\
\hline$X_{2}$ & 0.106 & 0.0039 & 2.7 & $*$ \\
\hline $\mathbf{X}_{3}$ & -0.087 & 0.056 & -1.6 & NS \\
\hline $\mathrm{X}_{4}$ & -0.236 & 0.20 & -1.2 & NS \\
\hline$X_{5}$ & -11.4 & 8.7 & -1.3 & NS \\
\hline $\mathrm{X}_{6}$ & 13.0 & 12 & 1.1 & NS \\
\hline $\mathbf{X}_{7}$ & 0.763 & 0.30 & 2.6 & $*$ \\
\hline
\end{tabular}

* significant at the $95 \%$ level.

** significant at the $99 \%$ level.
Sensitivity analysis

Tests of the addition and deletion of observations were performed to evaluate the sensitivity of the model to the given set of data. Deletion of 3 observations changed the coefficients and $R^{2}$ little and did not change the interpretation of the results (Table 5). The slopes of age and organic matter remained different from zero at the 95 percent level, but $\mathbf{B}_{6}$, the coefficient for permit condition changed, and we fail to reject the hypothesis that it equals zero (Table 6). The slope of spoil returned $\left(B_{7}\right)$ remained zero, but addition of observations changed the slope of canal length, which we no longer reject as being different from zero.

\section{Tests for autocorrelation}

Tests for autocorrelation were performed using the Durbin-Watson statistic. The Durbin-Watson statistics for the vegetation restoration model (1.83)

Table 6. Effect of addition of four observations to the depth and vegetation restoration models.

\begin{tabular}{|c|c|c|c|c|}
\hline \multirow[t]{2}{*}{ Variable } & \multicolumn{4}{|c|}{$\begin{array}{l}\text { Depth Model } \\
\mathrm{R}^{2}=0.46\end{array}$} \\
\hline & Beta & Std. Error & T-Value & \\
\hline$X_{1}$ & -0.67 & 0.58 & 1.2 & NS \\
\hline $\mathbf{X}_{2}$ & $0.000 \mathrm{l}$ & 0.0001 & 1.5 & NS \\
\hline $\mathrm{X}_{3}$ & -0.0034 & 0.0013 & -2.5 & * \\
\hline$X_{4}$ & 0.014 & 0.0048 & 2.9 & $*$ \\
\hline$X_{5}$ & $-0.08 \mathrm{I}$ & 0.21 & -0.39 & NS \\
\hline$X_{6}$ & 0.46 & 0.27 & 1.71 & NS \\
\hline$X_{7}$ & -0.0060 & 0.0065 & -0.93 & $\mathrm{NS}$ \\
\hline \multirow[t]{2}{*}{ Variable } & \multicolumn{4}{|c|}{$\begin{array}{l}\text { Vegetation Restoration Model } \\
\mathrm{R}^{2}=0.75\end{array}$} \\
\hline & Beta & Std. Error & T-Value & \\
\hline$X_{i}$ & -55.27 & 26.1 & -2.0 & NS \\
\hline$X_{2}$ & 0.0058 & 0.0039 & 1.5 & NS \\
\hline$x_{3}$ & -0.0406 & 0.060 & -0.68 & NS \\
\hline$X_{4}$ & -0.18 & 0.218 & -0.83 & NS \\
\hline$X_{5}$ & -17.3 & 9.49 & -1.8 & NS \\
\hline$X_{6}$ & 11.9 & 12.2 & 0.97 & NS \\
\hline$X_{7}$ & 1.22 & 0.29 & 4.2 & $* *$ \\
\hline
\end{tabular}

\footnotetext{
* significant at the $95 \%$ level.

** significant at the $99 \%$ level.
} 
fell into the zone in which we fail to reject autocorrelation. The statistic for the depth model (1.07) fell into the range in which we reject independence of the error terms. However, this is probably an artifact of the small sample size.

\section{Tests for heteroscedasticity}

A test was performed to examine whether variance with increasing canal length. Data were ranked by length. Variance was calculated separately for the 9 observations with the lowest length and the 9 observations with the greatest length. The 5 observations with intermediate length were dropped. For the depth model, the ratio of the variances was 1.06. An F-test with 3,3 d.f. $(F=5.39)$ causes a failure to reject the hypothesis of heteroscedasticity. The same test for the vegetation restoration model gives a ratio of 4.98 . The results of an F-test indicates failure to reject the hypothesis that the error terms have non-constant variance.

\section{Summary: Statistical models}

Canal age, soil organic matter content, and whether restoration was done as on-site or off-site mitigation were the most important predictors of canal depth (model $R^{2}=0.59$ ). Canal length and percentage of spoil returned $(+)$ had the greatest effect on vegetation cover (model $R^{2}=0.61$ ). Backfilled ca- nals were shallowed if they were older, in soils lower in organic matter, and backfilled off-site. Vegetation cover increased with increased canal length and percentage of spoil material returned. These results can be used to establish guidelines that will improve the overall success of backfilling.

\section{Backfilling cost}

Backfilling cost were estimated using the assumptions shown in Table 8. Backfilling restores wetlands at a cost of $\$ 1,200$ to $\$ 3,400 / \mathrm{ha}$, depending on whether only the direct, or also the indirect impacts, respectively, where included. The cost of dredging the original canal is about $\$ 25,000 / \mathrm{ha}$.

\section{Discussion}

Backfilling canals is a positive restoration measure for coastal Louisiana wetlands. The majority of the backfilled canals retained the same amount of vegetation in 1990 that was there in 1983/4. This result alone shows that the restoration achieved earlier has some stability. However, some backfilled canals show little restoration, and even deterioration. One backfilled canal (Mallard Bay; Site 9) was redredged between 1983/4 and 1990. Another lost most of the marsh around it and will probably soon

Table 7. Factors promoting restoration in backfilled canals.

\begin{tabular}{|c|c|}
\hline Factor & Influences Promoting Restoration \\
\hline \multicolumn{2}{|l|}{ Physical/Biological } \\
\hline Canal Depth & time between backfilling and dredging; up to 20 years shows benefits \\
\hline \multicolumn{2}{|c|}{ time since backfilling (decades) } \\
\hline Canal Length & $\begin{array}{l}\text { longer canals have higher re-vegetation rates, perhaps because dredge operators have more time to develop } \\
\text { skills }\end{array}$ \\
\hline Soils Condition & wetland organic content is inversely related to canal depth \\
\hline Surrounding Wetland & stability of surrounding wetland \\
\hline Sediment Supply & proximity to sediment sources \\
\hline \multicolumn{2}{|l|}{ Dredging Operation } \\
\hline Operator Skill & $\begin{array}{l}\text { longer canals have higher re-vegetation rates, perhaps because dredge operators have more time to develop } \\
\text { skills }\end{array}$ \\
\hline \multicolumn{2}{|l|}{ Management } \\
\hline Plug or No Plug in Canal & no apparent differences with or without plug \\
\hline Permitting Stipulations & $\begin{array}{l}\text { canals backfilled for mitigation are shallower than those backfilled after abandonment; one explanation is } \\
\text { related to the choice of sites by the dredge operator, or, the land manager. Off-site mitigation offers more } \\
\text { choices to dredge operators. }\end{array}$ \\
\hline
\end{tabular}


lose all vegetation in the canal. This may result from the natural slumping and filling in of older canals, which may offset the effect of decreased spoil volume that is thought to accompany greater age. Results of the model suggest that backfilling will be more successful at older canals.

The model results indicated that permits for backfilling would be more effective for longer canals. So few canals are presently being backfilled that it is unlikely that any one operator would have any backfilling experience. If that situation changed, one might expect operator experience to have a greater effect on restoration success. The model results also suggest that monitoring to ensure that as much of the existing spoil material is backfilled as possible would aid in increasing the success of restoration. The graphical analysis showed (Fig. 3) that depth increases with canal age up to some intermediate age (approximately 5 years) and then begins to decrease as canals progressively fill in. Changing the functional form of canal age by addition of a new variable (age 2) changed the amount of variation explained by the model only slightly $\left(R^{2}=0.55\right.$ compared to $R^{2}=$ 0.59 ).

Soil organic matter content has an important effect on canal depth. Canal depth decreases $15 \mathrm{~cm}$ for every 10 percent decrease in marsh soil organic matter content. There is a wide range of soil organic matter contents in Louisiana marshes, ranging from approximately 5 to 75 percent. On average, there is an approximately $1 \mathrm{~m}$ difference in canal depth at these extremes, if everything else is held constant. The model suggests that permits requiring backfilling would be more successful in marshes with lower organic content, that is, marshes near the coast or next to major rivers or bayous - precisely the areas in which alterations to hydrology by dredged canals are probably most severe. Backfilling these canals would help alleviate these harmful modifications and have a greater chance of successful restoration. Managers could use exising soil organic matter maps to evaluate backfilling permits.

Backfilled canals are $58 \mathrm{~cm}$ shallower if the driller had a choice of canals to backfill off-site. This suggests that an effective strategy for issuance of permits may be to allow a choice of canals to be filled for mitigation. Nevertheless, backfilling after abandonment appears to be an effective conservation strategy, despite the chance for greater restoration success at another location.

It appears that the most important factors influencing vegetation re-establishment are the canal length and the percentage of the spoil bank returned to the canal during backfilling. Both of these factors are probably related to the skill of the dredge operator. The more precise the operator's work, the more spoil can be returned without gouging the marsh or causing the marsh surface elevation to be too low. Also, the coefficient for length suggests that the hypothesis that longer canals allow dredge operators to learn better technique may be correct.

The major factors determining backfilling restoration success are the depth of the canal, soil type,

Table 8. Cost assumptions for calculating the cost of backfilling and its success.

\begin{tabular}{|c|c|c|}
\hline Item & Calculation Basis & Comments/Notes \\
\hline Cost & $\$ 1.20$ per $\mathrm{m}^{3}$ & $\begin{array}{l}\text { Industry based estimates that ignores the mobilization costs that may be } \\
\text { substantial for one effort, but trivial if the costs for multiple sites are } \\
\text { competitively bid. }\end{array}$ \\
\hline Canal Area & 1.3 ha & Median value of 31 backfilled canals. \\
\hline Spoil Area & 3.0 ha & Median value of 31 backfilled canals. \\
\hline Spoil Length & $880 \mathrm{~m}$ & $400 \mathrm{~m}$ canal length, 2 sides continuos spoil bank, and $80 \mathrm{~m}$ width at one end. \\
\hline Spoil Bank Width & $34 \mathrm{~m}$ & median value for 31 backfilled canals. \\
\hline Spoil Elevation & $0.3 \mathrm{~m}$ & Assume the peak of a triangle with a base of $34 \mathrm{~m}$. \\
\hline Indirect impacts & $1.85 \mathrm{ha} / \mathrm{ha}$ canal & Bass 1993. \\
\hline Restoration & $1.6 \mathrm{ha}$ & Median value for 31 backfilled canals. \\
\hline
\end{tabular}


canal dimensions, locale, dredge operator skill, and permitting conditions (Table 7). Plugging the canal has no apparent effect on water depth or vegetation cover, with one exception. Neill and Turner (1987a) noted that submerged aquatic vegetation was more frequently observed behind backfilled canals with plugs, than in backfilled canals without plugs. The decisions managers can constructively make when requiring backfilling is to choose among those candidate canals that are in low organic soils, longer, and near sources of suspended sediment supply. However, all canals with a healthy wetland around them should be included as potential backfilled sites. Even canals that are 20 years old may benefit from backfilling.

If complete wetland restoration to a pristine state were the goal of backfilling, then that goal has not been achieved. In the majority of cases marsh vegetation has not re-colonized the backfilled canal areas. The old spoil banks, in most cases and in varying degrees, have been re-vegetated by marsh vegetation. However, most also support upland vegetation at the outer portions that were not backfilled or on spots that were not backfilled to marsh elevations. There are also may examples of open water where the spoil banks were backfilled below marsh elevation. It is still a simple matter to discern the original configuration of the canal and spoil banks from aerial imagery taken 10 years after backfilling. In other words, the backfilled spoil areas are still distinct from the surrounding marsh habitat.

However, there have been benefits. Restoration of a more natural hydrological cycle has been achieved. Marsh areas which have been partially or completely impounded by spoil banks have fewer but longer periods of flooding and drying and reduced water exchange when compared to unimpounded marshes which respond more readily to the meteorologically and astronomically forced levels of estuarine waters (Swenson and Turner 1987). Visual studies of the aerial imagery of the backfilled canals show that many have developed dendritic drainage patterns which connect the marsh, former spoil banks, backfilled canals and (in cases where the canals were not plugged or where the plugs have eroded) the connecting wa- terways. Often, meandering channels are discernible in the backfilled canals. The interconnection of these components allows for the flux of material from and into the marsh area. Formerly impounded marsh areas can thus be the recipients of resuspended sediment from the bays and bayous (Reed 1989). By contrast, backfilled canals with intact plugs are clearly not receiving the suspended sediment that is available in the adjacent waterways. Plugged canals tend to be more uniformly deep and to have more aquatic vegetation. The aquatic vegetation in plugged canals offers good habitat for waterfowl and for fish, although the presence of an intact plug inhibits the movement of migrant fish species into and out of the canals.

The restoration costs compare favorably with funded restoration projects in south Louisiana (compared to Turner et al. 1994). For example, marsh management plans under the Coastal Restoration Act, 1990, cost in the neighborhood of $\$ 1,000$ to $\$ 90,000 /$ ha. Marsh management plans may be somewhat unpredictable or even damaging (Cowan et al. 1988; Cahoon et al. 1990), whereas these backfilled sites are based on empirical results. The estimated costs of river diversions are in the same cost range $(>\$ 10,000 / \mathrm{ha})$, but we have little experience with the reasonableness of the restoration estimates and the maintenance infrastructure is scheduled for 20 years. There are limited opportunities for building small river diversions, or splays, at the Mississippi River delta, although their cost is even less expensive (about $\$ 200$ to $\$ 400 /$ ha). Strategic cuts in spoil banks range around $\$ 10$ to $\$ 200 /$ ha restored (Turner et al. 1994).

In summary, backfilling as a means of managing the legacy of canals and spoil banks in coastal Louisiana is a management technique that demonstrates stability and even some improvement within a few years, but also over decades. It is a reasonably easy and quick management action, requiring simple equipment and no on-site maintenance. Fish and waterfowl habitat is produced. There are tens of thousands of hectares of canal and spoil banks available for backfilling today. Many more will become available for backfilling as the oil and gas fields close. 


\section{Acknowledgments}

A. Bass, L. Brunet, J. Medenblik, C. Milan, T.A. Oswald, G. Peterson, E. Swenson, M. Ying assisted in the field and laboratory work. Support for this project was received from the US Minerals Management Service, New Orleans, LA and an IPA from the National Marine Fisheries Service to J.M. Lee. We thank our colleagues at LSU who have discussed this subject with us over the years, especially K.L. McKee, I.A. Mendelssohn, G. Peterson, E. Swenson, J.P. Sikora and W.B. Sikora.

\section{References}

Bozeman, E.L. and Dean, J.M. 1980. The abundance of estuarine larval and juvenile fish in a South Carolina creek. Estuaries 3: 89-97.

Chabreck, R.H. 1979. Winter habitat of dabbling ducks - physical, chemical and biological aspects. pp. 133-142. In: Waterfowl and Wetlands - An Integrated Review. Edited by T.A. Bookhout. The Wildlife Society.

Cahoon, D.R. and Groat, C.G. editors 1990. A study of marsh management practice in coastal Louisiana. Final report 0001-30410 to the Minerals Management Service, New Orleans, La. OCS Study/ MMS 90-0075.

Cahoon, D.R. and Turner, R.E. 1989. Accretion and canal impacts in a rapidly subsiding wetland. II. Feldspar marker horizon technique. Estuaries 12: 260-268.

Cowan, Jr., J.H., Turner, R.E. and Cahoon, D.R. 1988. Marsh management plans in practice: do they work in coastal Louisiana? Environmental Management 12: 37-53.

Craig, N.J., Turner, R.E. and Day, Jr., J.W. 1979. Land loss in coastal Louisiana (U.S.A.). Environmental Management 3: 133-144.

Fredrickson, L.H. and Drobney, R.D. 1979. Habitat utilization by postbreeding waterfowl.pp. I19-131. In: Waterfowl and WetlandsAn Integrated Review. Edited by T.A. Bookhout. The Wildlife Society.

Gagliano, S.M., Meyer-Arendt, K.J. and Wicker, K.M. 1981. Land loss in the Mississippi River deltaic plain. Transactions Gulf Coast Association Geological Society 31: 295-300.

Neill, C. and Turner, R.E. 1985. An evaluation of backfilling canals as a means of mitigating the environmental impact of canals in south Louisiana: Atlas of backfilled canals. Report to the Coastal Management Division, Louisiana Department of Natural Resources, Baton Rouge, Louisiana, 192 pp.
Neill, C. and Tumer, R.E. 1987a. Backfilling canals to mitigate wetland dredging in Louisiana coastal marshes. Environmental Management 11: 823-836.

Neill, C. and Turner, R.E. 1987b. Comparisons of fish communities in open and plugged backfilled canals in Louisiana coastal marshes. N. Am. J. Fish. Managmt. 7: 57-62.

Ott, L. 1977. An Introduction to Statistical Methods and Data Analysis. Duxbury Press, North Scituate, Massachusetts.

Perry, G.W. 1976. Standing crops of fishes of an estuarine area in southwest Louisiana. Proc. 30th Annual Southeastern Fish and Wildlife Agencies 30: 71-81.

Reed, D.J. 1989. Patterns of sediment deposition in subsiding coastal marshes, Terrebonne Bay, Louisiana: The role of winter storms. Estuaries 12: 222-227.

Sasser, C.S. 1977. Distribution of vegetation in Louisiana coastal marshes as response to tidal flooding. M.S. Thesis, Louisiana State University, Baton Rouge. 40 pp.

Sikora, W.B. and Sikora, J.P. 1984. Benthos. In:Evaluation of Backfilling Canals as a Means of Mitigating the Environment Impact of Canals. Edited by R.E. Tumer, I.A. Mendelssohn, R. Costanza, K.L. McKee, C. Neill, J.P. Sikora, W.B. Sikora and E. Swenson. Final Rept. Coastal Management Section, Louisiana Department Natural Resources. Dec. 1984.

Snedecor, G.W. and Cochran, W.G. 1967. Statistical methods. Iowa State Univ. Press, Ames. Sixth Edition. 593 pp.

Swenson, E.M. and Turner, R.E. 1987. Spoil banks: Effects on a coastal marsh water level regime. Estuarine, Coastal and Shelf Science 24: 599-609.

Turner, R.E., Medelssohn, I.A., McKee, K.L., Costanza, R., Neill, C., Sikora, J.P., Sikora, W.B. and Swenson, E. 1988. Backfilling Canals in coastal Louisiana. Proc. National Wetlands Symposium: Mitigation of Impacts and Losses. Assoc. State Wetland Managers, Inc., New Orleans, Oct. 1986, pp. 135-141.

Turner, R.E. and Cahoon, D.R. (editors). 1987. Causes of Wetland Loss in the Coastal Central Gulf of Mexico. Vo. Executive Summary; Vol. 2: Technical Narrative. Vol. 3: Appendices. Final report submitted to Minerals Management Service, New Orleans, LA. Contract No. 14-12-00I-30252. OCS Study/MMS 87-0119.536 pp.

Turner, R.E., Swenson, E.M. and Lee, J.M. 1994. A rationale for coastal wetland restoration through spoil bank management in Louisiana. Environmental Management 18: 271-282.

Weinstein, M.P. 1979. Shallow marsh habitats as primary nurseries for fish and shellfish, Cape Fear River, North Carolina. Fish. Bull. 77: 339-357.

Corresponding Editor: Anonymous

Date received: December 12, 1993

Data accepted: May 1, 1994 